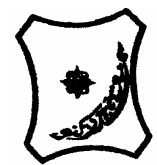

\title{
EFFECTS OF THE ETHANOLIC STEM BARK EXTRACT OF PTEROCARPUS ERINACEUS POI R (FABACEAE) ON SOME ISOLATED SMOOTH MUSCLES
}

\author{
Aliyu $M^{*}$ and Chedi B.A.Z. \\ Department of Pharmacology, Faculty of Medicine, Bayero University, Kano, Nigeria. \\ *Correspondence author: musaaliyu2005@yahoo.com
}

\begin{abstract}
Effects of the $70 \%$ ethanolic stem bark extract of Pterocarpus erinaceus Poir were investigated in some isolated smooth muscles preparations of experimental animals. Preliminary phytochemical studies of the ethanolic extract revealed the presence of tannins, carbohydrates, proteins, amino acids flavonoids and steroids. The ethanolic stem bark extract of P.erinaceus $(6.4 \mathrm{mg} / \mathrm{ml})$ relaxed the isolated pregnant rat uterus. Oxytocin induced contractions of the pregnant rat uterus was blocked by the extract at a higher dose. The studies on isolated guinea- pig ileum and rabbit jejunum smooth muscles demonstrated that the ethanolic stem bark extract of P.erinaceus produced a dose dependent relaxation of these muscles. The extract also attenuated the contractile effects of acetylcholine on these tissues dose dependently. This finding might lend credence to the use of the stem bark of the plant in the treatment of diarrhea and dysentery traditionally. From the results of this work and information from literature, flavonoids and tannins identified during phytochemical screening of the extract may be the biologically active components responsible for the gastrointestinal effects of the ethanolic stem bark extract of P.erinaceus.
\end{abstract}

Key words: Pterocarpus erinaceus, smooth muscles, relaxation, diarrhoea, dysentery.

\section{INTRODUCTION}

There is an increasing use and popularity for traditional medicine throughout the world nowadays. In industrialized countries, adaptation of traditional medicine is termed "Complementary" or "Alternative" medicine (CAM). Many of the pharmaceuticals currently available to physicians have a long history of use as herbal remedies, including opium, aspirin, digitalis, and quinine. The World Health Organization (WHO) estimates that 80 percent of the population in some Asian and African countries depends on traditional medicine for primary health care (WHO, 2008).

Plants represent the principal means of therapy in traditional medicine and the plant kingdom has long served as a prolific source of useful drugs. African indigenous herbal medicines are widely used throughout the African continent, despite the apparent lack of scientific evidence for their quality, safety and efficacy (Amos et al., 2002). The chemical constituents in medicinal plants usually explain the rational for the use of the plants in traditional medicine. The trend now is that phytochemists exploit medicinal plants and isolate bioactive compounds from which different analogues are synthesized with the aim of obtaining agents with better actions or even different biological properties. Plant's active constituents thus serve as templates for future drug developments.

Pterocarpus erinaceus is a perennial deciduous legume tree of African Savannas and dry forest popularly known as, African rosewood, African kino, or teak (in English). In northern Nigeria it is called "madobiya", "sha jinni"," banuhi", "zanchi" while in the south, it is called "apepe", "era", "osun dudu" or "upeka".The Ghanaians call it "senyo", bunernga" or "doti". The people of Ivory Coast refer to it as"modia baka" or "tolo"

In traditional medical practice, the leaf infusion is used in Ghana for fever (Irvine, 1961). The bark and resin decoction is an astringent for severe diarrhea and dysentery. The bark decoction has also been used for the treatment of tumors of the gland, urethral discharges and as restorative. The bark, as a dressing, is used on ringworm of the scalp and chronic ulcers (Dalziel, 1948). In Northern Nigeria, the bark is used as an ingredient in abortifacient prescriptions (Dalziel, 1948). Previous studies by Aliyu et al. (2005) showed that the ethanolic stem bark extract of the plant possesses significant and dose- dependent analgesic and anti-inflammatory activities in laboratory rats and mice. The ethanolic stem bark extract of the plant has also shown haemostatic activity in another study (Salawu et al., 2008). The aim of this experiment is to scientifically asses the basis of the traditional use of the stem bark of Pterocarpus erinaceus in the treatment of diarrhea, dysentery and as an abortifacient by studying the effect of ethanolic stem bark extract of the plant on isolated smooth muscles of guinea pig ileum, rabbit jejunum and pregnant rat uterus.

\section{MATERI ALS AND METHODS \\ Drugs and chemicals}

Drugs and chemicals used include; Histamine (Sigma, 94H0727), Oxytocin (Sigma,83H58052), Acetylcholine (Sigma,35H0784), 99\% ethanol. 


\section{Laboratory Animals}

Mature wistar rats $(160-250 \mathrm{~g})$ of both sexes were purchased from the National Veterinary Research Institute Vom, Nigeria. They were kept in clean cages under 12/12 hours normal light/dark cycle and allowed to acclimatize to the laboratory environment for a period of four (4) weeks before the commencement of the experiment. They were fed on standard pellet diet and water ad libitum during the stabilization period.

Guinea pigs and rabbits of both sexes used in the experiment were purchased locally from Samaru market, Zaria, Nigeria. They were kept in animal house and allowed to adjust to laboratory environment for a period of three (3) weeks before commencement of the experiment. They were fed with carrot leaves and provided water ad libitum during the stabilization period.

\section{Collection of Plant Material}

The stem bark of Pterocarpus erinaceus was collected along Burunburun village in Tudunwada local government area of Kano state, Nigeria. The plant was taxonomically identified and authenticated by Mal. Musa of the Botany Department of Ahmadu Bello University Zaria, Nigeria. A voucher specimen (No 900063) was made and deposited at the herbarium.

\section{Extract Preparation.}

The stem bark was air-dried for 30 days. It was then reduced to powdered form by grinding in pestle and motar. One hundred and sixty grams $(160 \mathrm{~g})$ of the powdered stem bark was cold macerated in $1000 \mathrm{ml}$ of $70 \%$ ethanol for 24 hours with constant shaking and filtered using Whatmans filter paper No.1.It was then concentrated to dryness on a water bath. The percentage yield was calculated and the crude extract was kept in a desiccator. When required, a known quantity of the extract was taken, dissolved in a known volume of distilled water to obtain the desired concentration.

\section{Phytochemical Studies}

Phytochemical analyses of the extract were performed according to the methods of Odebiyi and Sofowora (1978) and Trease and Evans (2004). The extract was screened for the presence of alkaloids, saponins, tannins, flavonoids, carbohydrates, proteins and steroids.

\section{Studies on the I solated Rabbit Jejunum}

The rabbit was starved for one day before use, sacrificed and the abdomen was opened. Segments of the jejunum about $2-3 \mathrm{~cm}$ long were removed and dissected free of adhering mesentery. The intestinal content was removed by flushing with Tyrode solution. The tissue was mounted in a $25 \mathrm{ml}$ organ bath containing Tyrode's solution at $37^{\circ} \pm 1^{\circ} \mathrm{C}$ and aerated with air. A 60 min equilibration period was allowed during which the physiological solutions was changed every $15 \mathrm{~min}$. At the end of the equilibration period, the effects of acetylcholine $(0.0004 \mu \mathrm{g} / \mathrm{ml}-$ $0.0032 \mu \mathrm{g} / \mathrm{ml})$ and extract $(0.4 \mathrm{mg} / \mathrm{ml}-3.2 \mathrm{mg} / \mathrm{ml})$ were investigated. The contact time for each concentration was $60 \mathrm{sec}$, which was followed by washing three times. The tissue was allowed resting period of $15 \mathrm{~min}$ before the next addition. Responses were recorded by a recording micro dynamometer (Amos et al., 1998).

\section{Studies on Guinea pig I leum}

Guinea pigs of either sex were starved of feed over night, sacrificed and the abdomen opened. A segment of the ileum $(2-3 \mathrm{~cm})$ was taken and dissected free of adhering mesentery and mounted in a $20 \mathrm{ml}$ organ bath containing Tyrode solution aerated with air and maintained at $37^{\circ} \mathrm{C}$. The tissue was equilibrated for 60 min with the Tyrode solution replaced after every $10 \mathrm{~min}$.At the end of the equilibration period, effects of the extract $(8 \mu \mathrm{g} / \mathrm{ml}-3.2 \mathrm{mg} / \mathrm{ml})$, Acetylcholine $(0.04-$ $0.16 \mu \mathrm{g} / \mathrm{ml})$ and histamine $(0.8-3.2 \mu \mathrm{g} / \mathrm{ml})$ were investigated on the preparation and recorded on Ugo Basile Unirecorder 7050.

\section{Test on I solated Pregnant Rat Uterus}

Female pregnant wistar rat weighing $180 \mathrm{~g}$ was sacrificed and the abdomen exposed, foetuses were removed. The horns of the uterus were freed and dissected out of the adhering tissue. A piece measuring about $2 \mathrm{~cm}$ was cut out and mounted in a $25 \mathrm{ml}$ organ bath with Dejalon's solution. The solution was maintained at $37 \pm 1{ }^{0} \mathrm{C}$, aerated with $95 \%$ oxygen and $5 \%$ carbon dioxide. A $60 \mathrm{~min}$ equilibration period was allowed during which the physiological solution was changed every $15 \mathrm{~min}$. At the end of the equilibration period, the effects of oxytocin (0.002$0.008 \mathrm{iu} / \mathrm{ml}$ ) and the extract $(4 \mathrm{ug} / \mathrm{ml}-6.4 \mathrm{mg} / \mathrm{ml}$ ) were investigated.

The contact time for each concentration was $60 \mathrm{sec}$, which was followed by washing three times. The tissue was allowed to rest for $15 \mathrm{~min}$ before the next addition. Responses were isometrically recorded with a micro dynamometer Ugo Basile Unirecorder 7050.

\section{RESULTS}

Effect of Extract on isolated Rabbit Jejunum

Acetylcholine $(0.0004-0.0032 \mathrm{ug} / \mathrm{ml})$ caused a concentration dependent contraction of the rabbit jejunum, while the extract $(0.8-3.2 \mathrm{mg} / \mathrm{ml})$ produced a dose dependent inhibition of the spontaneous contraction of the jejunum. The extract attenuated acetylcholine induced contraction of the rabbit jejunum concentration dependently (Fig.1). 


\section{Effect of Extract on Guinea Pig I leum.}

$P$. erinaceus extract $(8 \mathrm{ug} / \mathrm{ml}-1.6 \mathrm{mg} / \mathrm{ml})$ exerted a relaxant effect dose dependently on the guinea pig ileum. Acetylcholine $(0.04-0.32 \mu \mathrm{g} / \mathrm{ml})$ caused a concentration dependent contraction of the guinea pig ileum. $P$. erinaceus reduced the contractile effect of acetylcholine dose dependently.

Histamine $(0.8-3.2 \mu \mathrm{g} / \mathrm{ml})$ also caused a concentration dependent contraction of the guinea pig ileum which

\section{Table 1. Preliminary Phytochemical Screening of Ethanolic Stem-bark Extract of} Pterocarpus erinaceus

\begin{tabular}{lc}
\hline Compound group & Present/ Absent \\
\hline & + \\
Steroids & + \\
Carbohydrates & + \\
Proteins & + \\
Amino acids & + \\
Alkaloids & + \\
Saponins & - \\
\hline
\end{tabular}

was slightly reduced by $P$. erinaceus extract (400$800 \mu \mathrm{g} / \mathrm{ml}$ ) (Fig.2).

\section{Effect of Extract on Pregnant Rat Uterus}

The extract at $4 \mu \mathrm{g} / \mathrm{ml}$ to $3.2 \mathrm{mg} / \mathrm{ml}$ doses did not produce any effect on the pregnant rat uterus. However, full relaxation was observed at $6.4 \mathrm{mg} / \mathrm{ml}$ dose. The extract also attenuated contractions produced by $0.008 \mathrm{iu} / \mathrm{ml}$ Oxytocin dose dependently (Fig.3).
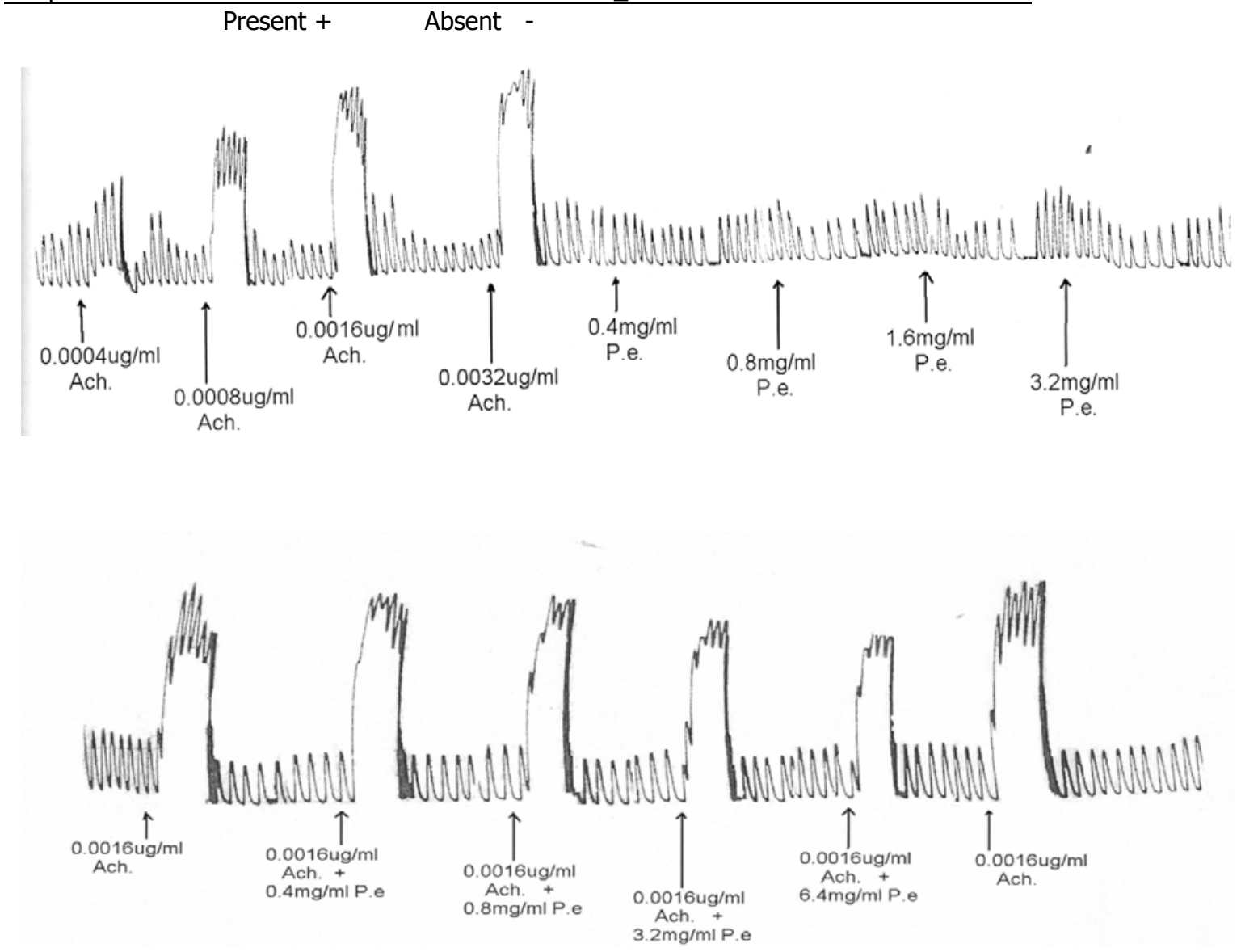

Figure 1: Effect of Ethanolic Stem Bark Extract of $P$. erinaceus on the Rabbit J ejunum 


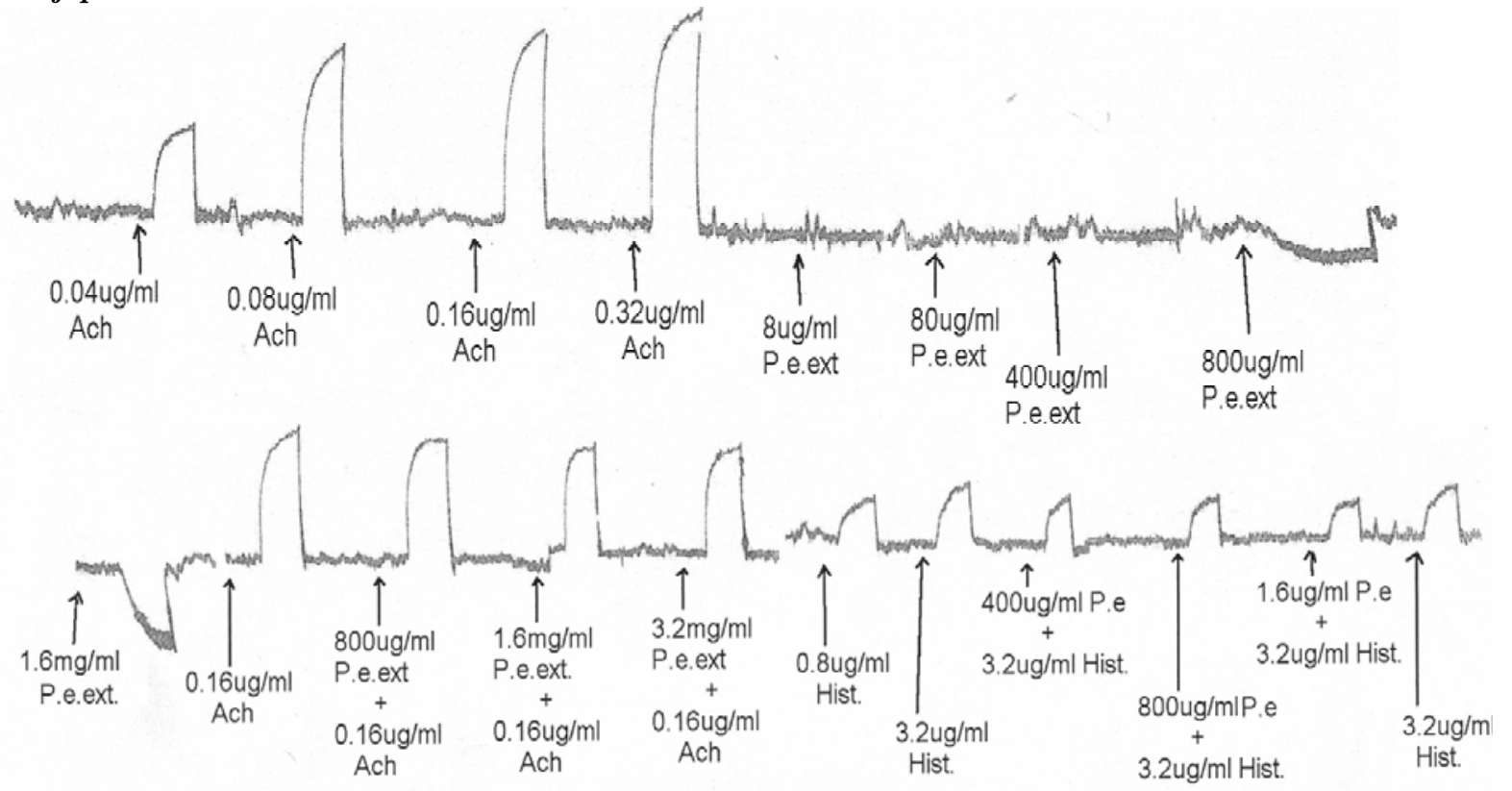

Figure 2: Effect of Ethanolic Stem Bark Extract of $P$. erinaceus on Guinea pig ileum
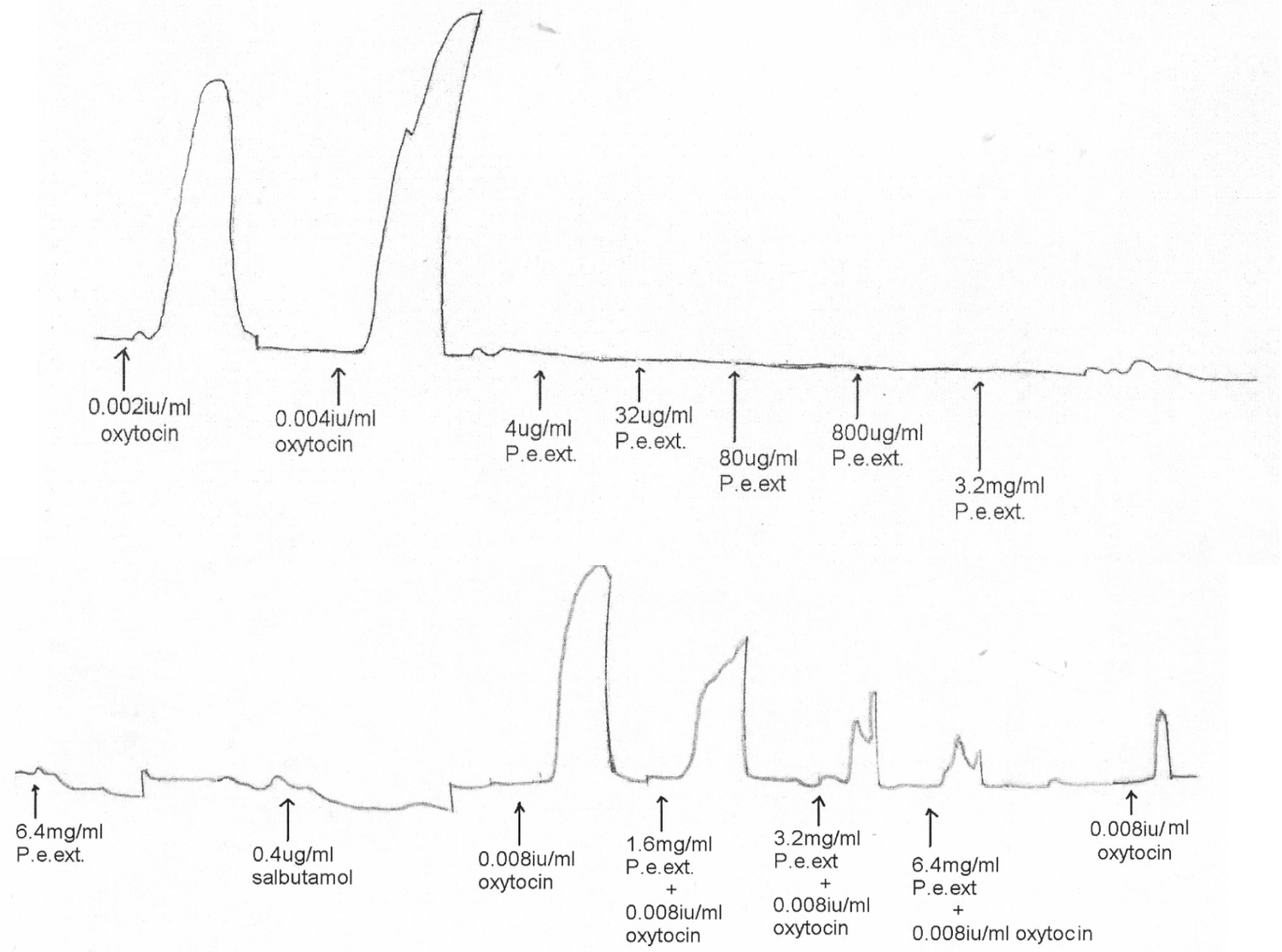

Figure 3: Effect of Ethanolic Stem Bark Extract of $P$. erinaceus on pregnant rat uterus

\section{DISCUSSION}

Medicinal plants are known to possess various phytochemical principles, which are responsible for their pharmacological activities and some side effects. Phytochemical analysis of the extract revealed the presence of carbohydrates, tannins, flavonoids, steroids, proteins and amino acids while alkaloids and saponins were however not detected (Table. 1) which could be responsible for its pharmacological actions. Previous work by Aliyu et al. (2004) also reported the same. 
Clinically diarrhea may result from disturbed bowel function, in which case there is impaired intestinal absorption, excessive intestinal secretion of water and electrolyte, and a rapid bowel transit (Gurgel et al., 2001).

Acetylcholine binds to muscarinic receptors on ileal smooth muscles causing the receptor-operated channel to open thus allowing sodium influx, which causes depolarization of the cell membrane. This depolarization opens voltage- dependent calcium channels and calcium ions enter the cell to induce the release of calcium from sarcoplasmic reticulum. The cytosolic calcium then binds to calmodulin and contraction is produced (Bolton, 1979). Histamine binds to $\mathrm{H}_{1}$ receptor on gastrointestinal smooth muscle to initiate the same sequence of events (Bohr, 1973). An elevation of intracellular $\mathrm{Ca}^{2+}$ level by influx from extracellular compartment or release from intracellular store also results in contraction. (Ebeigbe, 1982).

Slight inhibition of acetylcholine and histamine-induced contraction of the rabbit jejunum and guinea pig ileum shows that the extract interacts with both muscarinic and histaminic receptors. The extract could possibly prevent calcium influx through the voltage operated channels by inhibiting the calcium induced calcium release mechanism preventing the release of calcium from the sarcoplasmic reticulum, closing of sodium and calcium ion channels,activation of second messengers like CAMP or preventing binding of calcium to calmodulin.

Antidiarrheal properties of medicinal plants were found to be due to tannins, alkaloids, saponins, flavonoids, sterols and/or triterpenes and reducing sugars (Longanga et al., 2000). This activity could be linked to the presence of

\section{REFERENCES}

Aliyu, M,. Salawu, O.A., Wannang, N.N., Bichi, L.A (2004). A pleriminary pharmacognostical studies of the stem bark of Pterocarpus erinaceus. Afr.J.Mater.Nat. Sci. 4(1): 79-8.

Aliyu, M., Salawu, O.A., Wannang, N.N.,Yaro, A.H and Bichi, L.A (2005): Analgesic and antiinflammatory activities of the ethanolic extract of the stem bark of Pterocarpus erinaceus in mice and rats. Nigerian Journal of Pharmaceutical Reaserch. 4(2), pp12-17

Amos S, Okwuasaba F.K, Gamaniel K, Akah P, Wambebe C. (1998). Inhibitory effects of the aqueous extract of Pavetta crissipes leaves on gastrointestinal and uterine smooth muscle preparations isolated from rabbits, guinea pig and rats. J ethnopharmaco/ 61:209-213

Amos S, Chindo B, Edmond I, Akah P, Wambebe C, Gamaniel K (2002). Anti-inflammatory and antinociceptive effects of Fiscus platyphylla in rats and mice. J.Herbs, Spices and Med. Plants. 9:47-53

Bohr, D.F (1973): Vascular Smooth Muscles updated. Circ. Res.32: pp.665-672.

Bolton,T.B.(1979). Mechanism of Action of transmitters and other substances on smooth muscles. Physiol; Rev.59: pp.606-718.

Dalziel, J.M. (1948): The Useful Plants of West Tropical Africa. The Crown Agents for the colonies. London pp 612.

Ebeigbe,A.B.(1982): Calcium pools for Noradrenaline and potassium induced contraction of RatPortal tannins and flavonoids found during phytochemical screening of the extract.

Oxytocin, a neurohypophyseal polypeptide released by posterior pitutuary stimulates both frequency and force of contraction of uterine smooth muscles. The action of oxytocin on myometrium is independent of innervation. There are specific oxytocin receptors, which mediate the response mainly by depolarization of muscle fibres, influx of calcium ions and intracellular release of calcium ions. The ethanolic bark extract of Pterocarpus erinaceus $(6.4 \mathrm{mg} / \mathrm{ml})$ produced relaxation of the smooth muscle of the isolated pregnant uterus of rat. Oxytocin induced contraction was also blocked by the ethanolic extract possibly by inhibiting prostaglandin synthesis thus reducing the concentration of endogenous prostaglandins $\left(E_{2} \& F_{2} a\right)$ necessary for uterotonic action. Non-steroidal anti-inflammatory agents like piroxicam act principally by inhibiting activity of cyclo-oxygenase enzyme (COX), nonselectively, leading to a decrease in the production of prostaglandins (Hiruma-Lima et al., 2006). Since the invitro studies conducted during this work did not support the ethno-medical use of P.erinaceus as part of abortifacient prescription, this may suggest that the plant may not be the active abortifacient constituent of the prescription.

\section{CONCLUSION}

The ethanolic stem bark extract of Pterocarpus erinaceous relaxed smooth muscles of guinea pig ileum and rabbit jejunum in -vitro. This probably explains the use of the plant stem bark in the treatment of diarrhea and dysentery by traditional healers. The extract also relaxed the pregnant rat uterus, which is not in conformity with its claimed use as an ingredient in abortifacient preparations traditionally.

Vein, Canad.J. Physiol Pharmacol.60:pp.12251227.

Gurgel, L.A., Santos, F.A., Martins, D.T.O., Mattos, P.O., Rao, V.S.N. (2001): Studies on the Antidiarrheal effect of dragon's blood from Croton urucurana, Phytother. Res. 15: 319-322

Hiruma-Lima, T.R.,Calvo, C.M., Rodrigues, F.D.P.,Andarde,W., Velegas and Brito A.R.M.S. (2006): Anti-ulcerogenic activity of Alchornea castaneaefolia: effects on somastostatin, gastrin and prostaglandin. Journal of Ethnopharmacology 104, pp 215-224.

Irvine, F.R. (1961): Woody Plants of Ghana. Oxford University Press. London pp 868.

Longanga-Oushudi, A., Vercruysse, A., and Foriers A. (2000). Contribution to the Ethnobotanical, Phytochemical and Pharmacological studies of traditionally used medicinal plants in the treatment of dysentery and diarrhea in Lomela area, Democratic Republic of Congo (DRC), Journal of Ethnopharmacology, 71, 3, 411-23.

Odebiyi, O.O. and Sofowora, E.A. (1978). Phytochemical Screening of Nigerian Medicinal Plants. Part II, Llyodia, 41, 234

Salawu, O.A., Aliyu, M. and Tijani, A.Y. (2008): Haematological studies on the ethanolic stem bark extract of Pterocarpus erinaceus Poir (Fabaceae). African Journal of Biotechnology Vol. 7(9), pp 1212-1215

Trease, G.E. and Evans, W.C. (2004). Pharmacognosy. Williams Charles Evans as edited in $15^{\text {th }}$ edition. Saunders publisher London pp. 137-440.

W.H.O, (2008): Traditonal Medicine. Fact sheet no.134, 